Dept. of Vet. Medicine,

Faculty of Vet. Med., Assiut University,

Head of Dept. Prof. Dr. M.F. Raghib.

\title{
PLASMA PROTEINS AND LIPID CONTENTS IN BLOOD SERUM OF SUBCLINICAL FATTY IIVER IN FRIESIAN COWS (With 3 Tables)
}

By

\author{
A.A. DAKKA*; M.F. RAGHIB and A.H. SADIEK \\ (Received at $28 / 7 / 1992$ )
}

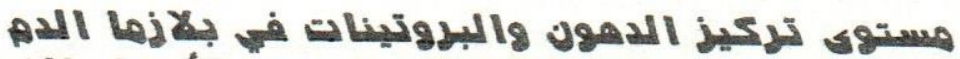

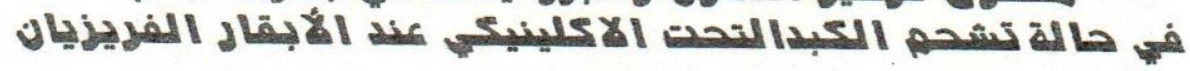

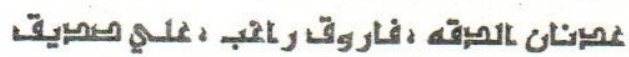

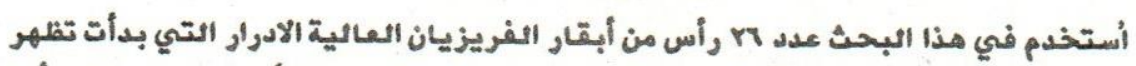

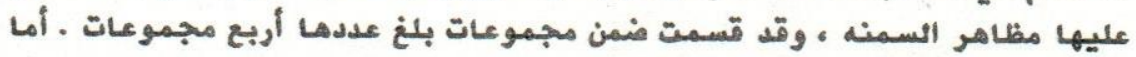

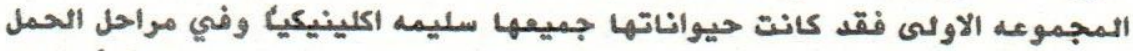

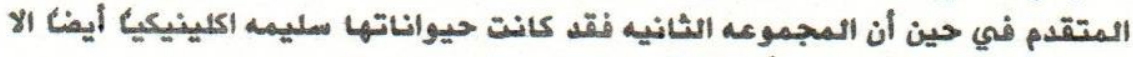

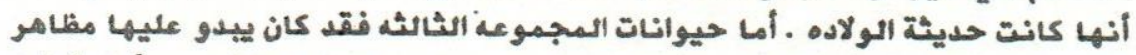

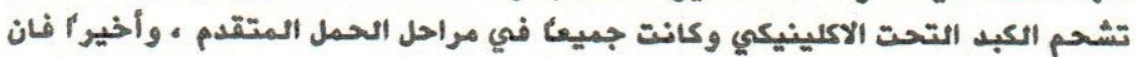

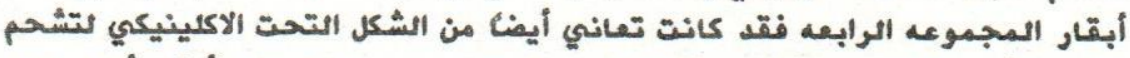

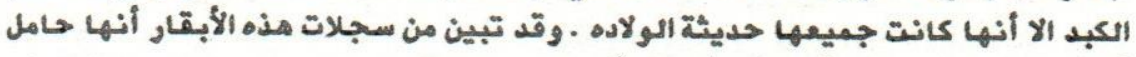

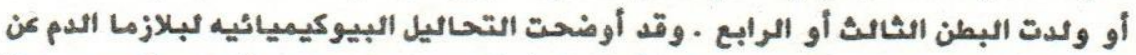

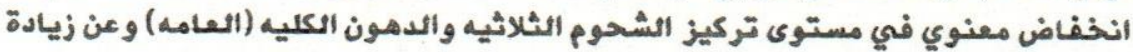

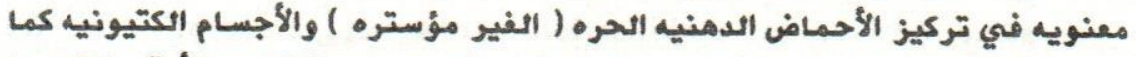

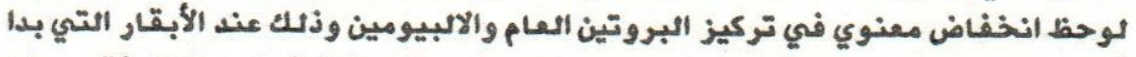

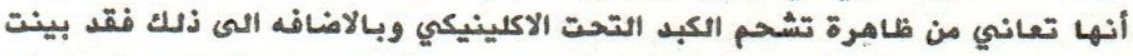

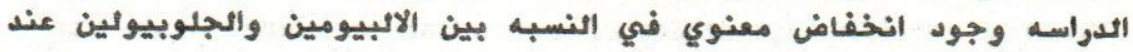

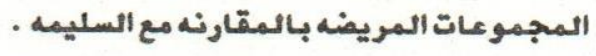

*: Prof. and head of Dept., Fac. Vet. Med., El-Baath Univ. S.Y.R. 


\section{SUMMARY}

A total number of 26 dairy friesian cows were used in this study. The animals were selected and classified into four groups. The first group was at late pregnancy and clinically healthy, the second group was clinically healthy also but the cows were recently parturated. The 3rd and 4th groups were cows suffering from subclinical fatty liver syndrome where cows of the 3rd group were at late pregnancy and those of the 4 th group were recently parturated. higher body condition score (BCS) was observed in both groups (II \& IV). The analysis of blood serum revealed significant decreased levels of triglycerides (TG), total Lipids, total proteins and albumin in the diseased cows when compared with the healthy ones. Meanwhile a significant increase in the non esterified fatty acidy (NEFA), as well as Beta hydroxybutyrate levels (BHB) in diseased groups was evident. In addition albumin/ globulin ratio (A/G) was also significantly decreased in the diseased groups.

\section{INTRODUCTION}

A condition of fatty liver syndrome has been previously reported in certain dairy stations in Assiut Governorate Egypt. (EL-SEBAIE, 1987 and SADIEK, 1992). The authors recorded high losses among recently parturated dairy cows from the disease it self as well as from the associating disorders.

Subclinical fatty liver developing in dairy cows at early lactation has been reported (FRONK, et al. 1980; REID, 1980; TREACHER, et al. 1981 a and REID and ROBERTS, 1982), where subclinical fatty liver have been diagnosed in high proportion of dairy cows particularly in the obese cows which loose weight directly after calving.

Excessive rate of fat mobilisation and development of fatty liver at early lactation are deleterious for health and productivity of dairy cows (MORROW, 1976 and McCORMARCK, 1978).

Feeding excessive quantities of concentrate combined with free choice access of corn silago and/or hay crop forage during both late lactation and dry period are incriminated to be the usual causitive factors for the development of fatty liver disease (MORROW, 1976). 
Decreased protein synthetic capacity of the liver in cows with fatty liver thas been reported (REID, et al. 1983).

Fatty liver disease was reported by many workers to be associated with decreased serum albumin concentration (REID, 1980; ROWLAND and REID, 1982; BOGIN, et al. 1984 and SADIEK, 1992) suggesting that this probably is an indication of reduced protein synthetic capacity of the liver. Marked reduction in the protein synthetic machinary (the rough endoplasmic reticulum) in liver cells was observed in hepatic tissues of cows with fatty liver (REID, et al. 1987).

The reduced liver function in cows with fatty liver syndrome (FCS) could also worsened by the high incidences of secondary disorders which may help in the explanation of the reduced albumin in these cows (BOGIN, et al. 1988 and SADIEK, 1992).

ROBERT, et al. (1981) illustrated the relationship between various measurement of fat mobilisation and deposition at early lactation in cows with fatty liver. The authors revealed a positive correlation between liver fat and NEFA $(0,84)$. Similar observation was reported by COLLINS and REID (1980) confirming the relationship between the severity of fatty liver and extent of body fat mobilisation. High blood serum NEFA concentration was reported in all cases of fatty liver and it was positively correlated with the degree of fatty liver (MORROW, 1976; MORROW, et al. 1979).

High levels of ketone bodies were recorded directly after calving in cases of fatty liver disease as an indication to negative energy balance (MORROW, et al. 1979 and SADIEK, 1992). Significant drop of triglycerides (TG) in the blood and in all lipoprotein fractions at calving was reported by HERDT, et al. (1983).

As far as total lipids are concerned in fatty liver disease of dairy cows, there was reduction in the amount of total lipids as a result of the decrease in the amount of triglycerides and cholesterol (BOGIN, 1988; GRIMOLDI, et al. 1988 and SADIEK, 1992).

The aim of the present investigation is to study the possible changes occurring in the obese dairy cows during subclinical fatty liver disease.

\section{MATERIAL and METHODS}

A total number of 26 dairy friesian cows were used in this study from Abnoub El-Hammam dairy farm in Assiut Governorate Egypt, animals 
were selected and classified into four groups as shown in table 1.

Animals in the control groups were fed ration relatively high in protein, where in summer the ration consisted of concentrate mixture $(20 \%$ Crushed maize, $10 \%$ soya bean, $35 \%$, wheat bran and $32 \%$ cotton seed meal and limestone and $1 \%$ common salt). The amount of concentrate mixture offered was 6-8 $\mathrm{kgm}$ per cow. In winter green feed was available in a quantity of $20-40 \mathrm{kgm}$ of barseem per head daily.

The same concentrate mixture given in summer was given in winter, but by 4-5 $\mathrm{kgm}$ per head daily. The two groups which were suffering from subclinical cases of fatty liver were fed during summer concentrate mixture consisted of $30 \%$ crushed maize, $32 \%$ cotton seed meal and $35 \%$ wheat bran. The source of mineral was the same as in control groups and also given green feeds.

In winter the same green feed (barseem) was given in the same amount as in control groups but the concentrate mixture was the same given in summer to the cows with subclinical fatty liver by the amount of 4-5 kgm per head daily. Cows suffering from subclinical fatty liver were choosen according to the appeared signs of obesity (BCS) and the general status of these animals anticipated from the given ration which was high relatively in carbonacious concentrates.

Body condition score (BCS) was evaluated according to the method adopted by GERLOFF (1987). Blood serum samples were collected from the control groups and from the groups of subclinical fatty liver at one time. Blood serum samples were analysed colorometrically for total protein $(\mathrm{g} / \mathrm{L})$ and albumin $(\mathrm{g} / \mathrm{L})$ by test kits supplied by Boehringer Mannheim. Triglycerides (mmol/L) and total lipid $(\mathrm{g} / \mathrm{L})$ were estimated also by test kits supplied by Boehringer Mannheim according to the method described by KIRCH and ZOLLNER (1962). Meanwhile NEFA level (mmol/L) was determined using testkits supplied by WAKO industries Osaka, Japan. BHB was determined by using test kits suplied by Sigma Chemical company (USA). The obtained results were statistically analysed on the basis of SENDECOR and COCHRAN (1967) calculations.

\section{RESULTS}

High body condition score was observed among cows with subclinical fatty liver (groups II \& IV), it was ranged from 3-4 in group II and 3-3,5 in 
group IV. Mild to moderate reduction in appetite was detected in both groups (II \& IV).

The mean value and the standard deviations of the obtained results of blood triglycerides, NEFA and total lipid and BHB are illustrated in table 2 while the other results concerning plasma proteins are illustrated in table 3 .

\section{DISCUSSION}

It is clearly evident in this investigation that the ration given to the subclinically diseased groups with relatively high percent in the carbonacious concentrates is the possible cause of obesity among cows with subclinical fatty liver disease which evantually leeds to the precipitation of fat in adipose tissue of the cows during late pregnancy and dry period. There was a highly significant $(P<0.01)$ decreased amount of the blood serum total lipids and triglycerides in the subclinical diseased groups (Table 2). In healthy cows TG begin to decreased before calving indicating rapid decline at calving and increase afterward in early lactation (DUNCAN and CARTON, 1963; FRONK, et al. 1980 and KARSAI and GALL, 1987).

In case of fatty liver the TG accumulate in the liver cells and their secretion into the blood may be impaired due to insufficient lipoprotein formation (HOLTENIUS, et al. 1986).

It was reported that in cases of fatty liver, the liver cannot metabolises the all amount of mobilised NEFA and by turn it will be accumulates in the liver in the form of triglycerides (ROBERT, et al. 1981 and HOLTENIUS, et al. 1986) reflecting low level of TG in blood serum.

The highly significant increase $(P<0.01)$ in the level of NEFA in diseased groups if compared with the healthy cows is evident. This finding coincided with those previously obtained by SADIEK (1992) in a similar conditions in friesian cows.

The high significant increase $(P<0.01)$ of $B H B$ in both 2 nd \& 4th groups may be attributed to a condition of negative energy balance in these cows, the decreased appetite in these cows as well as overproduction of ketone bodies as a result of increased mobilisation of NEFA from body fat to the liver. All these may be the causes of such observation (Table 3).

As far as total proteins and albumin contents of both diseased groups are clearly significantly $(P<0.01)$ decreased when compared with control groups (Table 3 ). this could be attributed to the fatty liver infiltration in the 
begining of the disease which led to the decreased liver capacity for synthetising total blood serum protein and evantually albumin. These findings agreed with MORROW, et al. (1979). Furthermor it is clearly evident that in cows of fourth group which have already parturated, the amount of total proteins and albumin is relatively low when compared with the 3rd group. This is because cows of group No. III ate for a long period the ration which is relatively high in carboncious concentrates.

A/G ratio was significantly low $(P<0.05)$ in the diseased subclinical groups when compared with the healthy groups (Table 3 ). This reduction in blood serum A/G ratio coincided with many workers TREACHER, et al. 1981. Evantully such reduction in the $A / G$ ratio in the diseased groups could be explained by the occuring marked reduction in the blood serum albumin contents (Table 2).

Finally it could be concluded that the fatty liver disease has a subclinical phase which could be indicated by the measuring of the levels of blood serum total protein, albumin, A/G ratio and lipid contents mainly triglycerides and total lipids as well as BHB. Also it is clearly evident that giving ration with high energy contents will evantully leeds to precipitation of fat with the occurrance of fatty liver. This is because high energy ration is more than the needs of the cows especially when given at late lactation and dry period. For all mentioned data it is necessary to give the dairy cows ration on scientific basis according to their actual needs at the different stages of pregnancy and lactation.

\section{REFERENCES}

Bogin, E.; Avidar, Y.; merom, M.; Israeli, B.; Malkinson, M.; Soback, S. and Kudler, Y. (1984): Biochemical changes associated with fatty liver in geese. Avian Pathology, 13: 683-701.

Bogin, E.; Avidar, Y.; Merom, M.; Soback, S. and Brenner, G. (1988): Biochemical changes associated with fatty liver syndrome in cows. J. Comp. Pathology, 98: 337-347.

Collins, R.A. and Reid, I.M. (1980): A correlated biochemical and stereological study of periparturient fatty liver in the dairy cow. Res. in Vet. Sci., 28: 337-376.

Duncan, W.R.H. and Carton, G.A. (1963): Blood lipid. 3- plasma lipoprotein of cow during pregnancy and lactation. Bioch. J., 89: 414-418.

Assiut Vet. Med.J. Vol, 28, No. 55, October 1992. 
El-Sebaie, A. (1987): Fat cow syndrome: A clinical and biochemical observatons in a holstein friesian dairy herd. Assiut Vet. Med. J., 18 (36): 132-139.

Fronk, T.J.; Schultz, L.H. and Hardie, A.R. (1980): Effect of dry period overconditioning on subsequent metabolic disorders and performance of dairy cattle. J. Dairy Sci., 63: 1080-1090.

Gerloff, B.J. (1987): Body condition scoring in dairy cattle. Agri. Pract. 31-36.

Grimoldi, R.J.; Marquez, A.G.; Tirante, H.; Rutter, B.; Corujeira, M. and Gasal, G. (1988): Effect of partum and lactation on blood lipid in Holand Argentine cows (in Animal Clinical Biochemistry (1988) ed. by Blackmore, (1988). pp. 292-301. Combridge Uni Press combridge, New York, New Rochelle, Melbourne and Sydney.

Herdt, T.H.; Liesman, J.S.; Gerloff, B.J. and Emery, R.S. (1983): Reduction of serum triacylglycerol rich lipoprotein concentrations in cows with hepatic lipidosis. A.J.V. Res., 44: 293-296.

Holtenius, P.; Niskanen, R. and Holtenius, K. (1986): Blood lipids, and lipoproteins in cows with abomasal displacement. Proc. XIV World Cong. on Cattle Disease, Dublin, 47-51.

Karsai, F. and Gaal, T. (1987): Anderungen gewisser Kennwerte des Fettstoffwechsels bei Milchkuhen. Dtsch. tierarztl. Wschr., 94: 246-268.

Kirch and Zollner, (1962): Determination of blood serum total lipids. Z. Ges. Exp. Med., 135-136.

McCormack, J. (1978): Fat cow syndrome and its complications. Vet. Med. and Small Animal Clinician, 73: 1057-1060.

Marrow, D.A. (1976): Fat cow syndrome. J. Dairy Sci., 59: 1625-1629.

Morrow, D.A.; Hillman, D.; Doda, A.W. and Kithen, H. (1979): Clinical investigation of a dairy herd with fat cow syndrome. J.A.V.M.A., 174: 161-167.

Reid, I.M. (1980): Incidence and severity of fatty liver in dairy cows. Vet. Rec., 107: 281-284.

Reid, I.M. and Roberts, C.J. (1982): Fatty liver in dairy cows. Vet. Rec. Supplement in practice, 4: 164-169.

Reid, I.M. and Roberts, C.J. (1983): Subclinical fatty liver in dairy cows. Irish Vet. J., 37: 104-110.

Assiut Vet. Med.J.e. Vol, 28. No. 55. October 1992. 
Reid, I.M.; Rowlands, J.G.; Dew, A.M.; Collins, R.A.; Roberts, C.J. and Manston, R. (1983): The relationship between postparturient fatty liver and blood composition of dairy cows. J. Agri. Sci. Camp., 101: 473-480.

Roberts, C.J.; Reid, I.M. and Rowlands, G.J. (1981): A fat mobilisation syndrome in dairy cows in early lactation. Vet. Rec., 108: 7-9.

Rowlands, G.J. and Reid, I.M. (1982): The link between fatty liver, blood metabolites and fertility in dairy cattle. XII World Cong. on Cattle Disease (Amesterdam) Proc. Bd., 1: 533-536.

Sadiek, A.H. (1992): Clinical and biochemical studies on fatty liver syndrome on Holstein friesian cows. Ph.D. Thesis, Faculty of Vet. Med., Assiut University, Egypt.

Sneedcor and Cocharn (1967): Statistical methods 5th ed. Iowa State Univ. Press Ames Iowa, USA.

Treacher, R.J.; Reid, I.M. and Roberts, C.J. (1981): The effect of body condition at calving on the development of fatty liver and metabolic diseases. Animal Production, 32: 363-365. 
Table -1 :Group Classification.

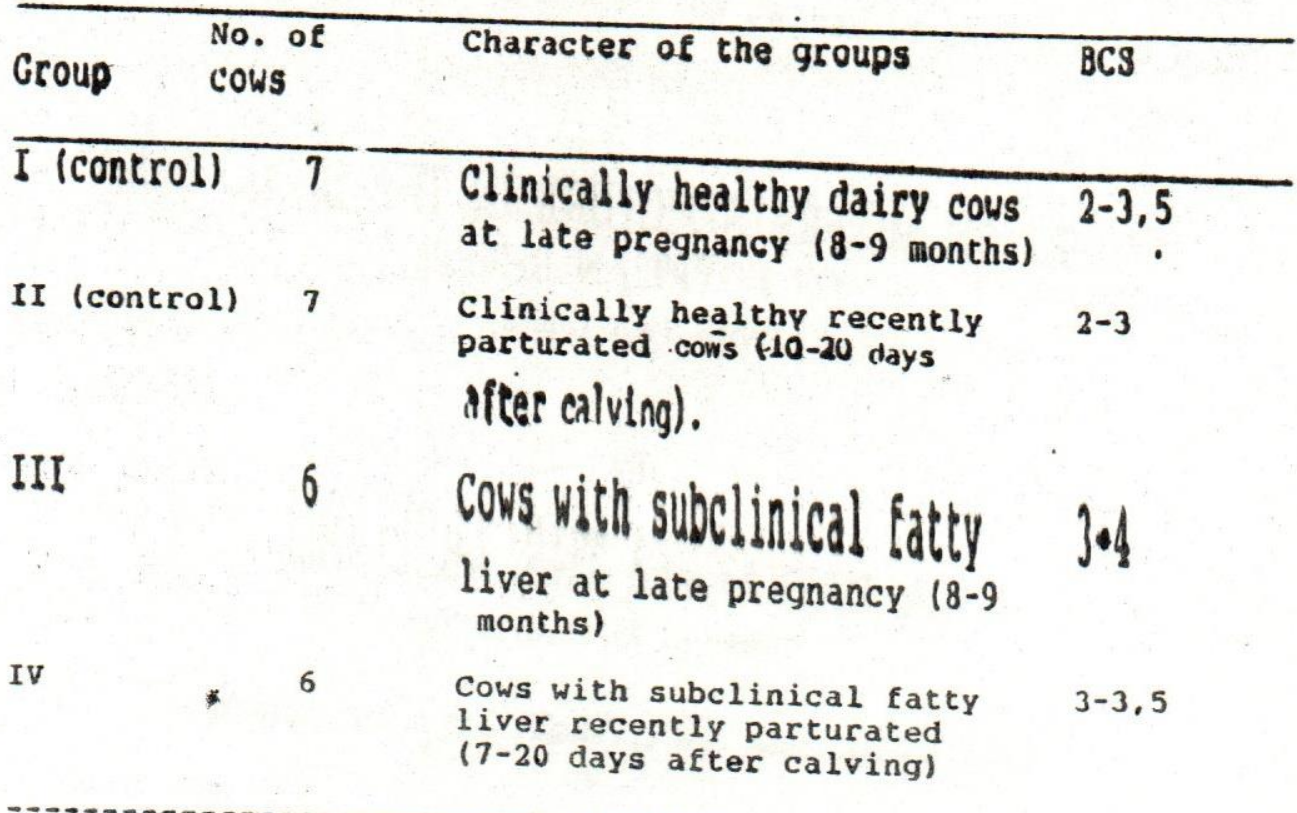

Tabie -2: Mean values and S.D. of lipid parameters in the healthy and subclinical cases of fatty liver syndrome.

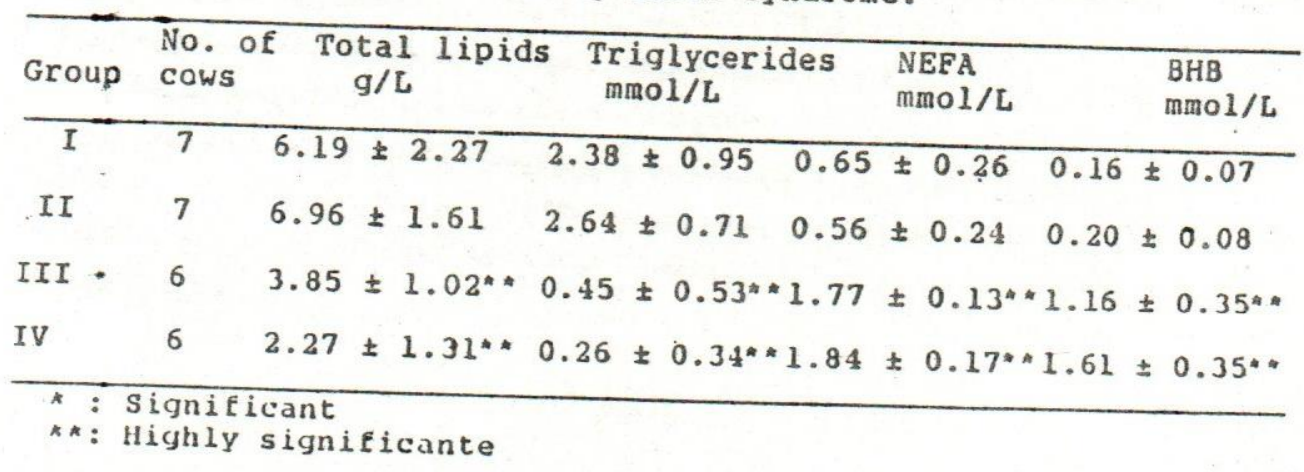

Table -3: Mean values and S.D, of plasma proteins in healthy and subclinical cases of fatty liver syndrome.

\begin{tabular}{lcccccc}
\hline Group & $\begin{array}{c}\text { No.of } \\
\text { cows }\end{array}$ & $\begin{array}{c}\text { Total protein } \\
\mathrm{g} / \mathrm{L}\end{array}$ & $\begin{array}{c}\text { Albumin } \\
\mathrm{g} / \mathrm{L}\end{array}$ & $\begin{array}{c}\text { Globulins } \\
\mathrm{g} / \mathrm{L}\end{array}$ & $\begin{array}{c}\text { Albumin/ } \\
\text { globulin } \\
\text { ratio }\end{array}$ \\
\hline I & 7 & $82.5 \pm 2.23$ & $43.3 \pm 2.23$ & $39.2 \pm 2.23$ & $1.11 \pm 0.418$ \\
II & 7 & $84.4 \pm 1.25$ & $42.5 \pm 1.15$ & $41.9 \pm 9.14$ & $1.21 \pm 0.433$ \\
III & 6 & $79.6 \pm 2.23^{*}$ & $38.2 \pm 1.17^{*}$ & $41.4 \pm 6.32$ & $0.93 \pm 0.299$ \\
IV & 6 & $76.5 \pm 1.15^{*}$ & $37.2 \pm 1.31^{*}$ & $39.3 \pm 7.14$ & $0.94 \pm 0.299^{*}$ \\
\hline$* \quad:$ Significant & & & & & &
\end{tabular}

